\title{
Template Synthesis, Crystal Structure, and Magnetic Properties of a Dinuclear Copper(II) Complex with Cooperative Hydrogen Bonding
}

\author{
Shin-Geol Kang, ${ }^{*}$ Kwanghee Nam, Kil Sik Min, ${ }^{\dagger}$ and Uk Lee ${ }^{\ddagger}, *$ \\ Department of Chemistry, Daegu University, Gyeongsan 712-714, Korea. *E-mail: sgkang@daegu.ac.kr \\ ${ }^{\dagger}$ Department of Chemistry Education, Kyungpook National University, Daegu 702-701, Korea \\ *Department of Chemistry, Pukyong National University, Busan 608-737 Korea. EE-mail: uklee@pknu.ac.kr \\ Received November 22, 2010, Accepted December 23, 2010
}

Key Words : Metal-directed condensation, Cooperative hydrogen bond, Dinuclear copper(II) complex, X-ray structure, Magnetic interactions

The design and synthesis of polynuclear transition metal complexes have received much attention because of their potential applications in various fields, such as catalysis, supramolecular chemistry, and materials chemistry. ${ }^{1-9}$ Until now, various types of dinuclear copper(II) complexes have been prepared and investigated. Some dinuclear copper(II) complexes resulting from cooperative hydrogen bonding, such as 2-4 containing two $\mathrm{N}_{2} \mathrm{O}_{2}$ donor sets, are also reported. $^{6-9}$ In 2-4, each mononuclear unit contains both hydrogen-bond donor and accepter groups. It has been revealed that the $\mathrm{Cu}-\mathrm{O}$ distances of $\mathbf{2}$ and $\mathbf{4}$ are shorter than the $\mathrm{Cu}-\mathrm{N}$ (primary or tertiary amino groups) distances. ${ }^{7}$ In the case of $\mathbf{3}$, however, the $\mathrm{Cu}-\mathrm{O}$ distances are longer than the $\mathrm{Cu}-\mathrm{N}$ (imino groups) distances. The $\mathrm{O}-\mathrm{H} \cdots \mathrm{O}$ and the $\mathrm{Cu} \cdots \mathrm{Cu}$ distances of 2-4 are influenced by their structural characteristics. $^{6-8}$ Furthermore, 2-4 are known to exhibit antiferromagnetic coupling. However, examples of such dinuclear copper(II) complexes with cooperative hydrogen bonding are relatively few, and the effects of the structural features on the hydrogen bonding and the antiferromagnetic coupling remain poorly understood. Therefore, we have been interested in the preparation of various types of dinuclear copper(II) complexes containing two $\mathrm{N}_{2} \mathrm{O}_{2}$ donor sets that linked together by cooperative hydrogen bonding.

$$
\begin{aligned}
& \mathrm{Cu}^{2+}+\mathrm{H}_{2} \mathrm{~N}\left(\mathrm{CH}_{2}\right)_{3} \mathrm{NH}\left(\mathrm{CH}_{2}\right)_{2} \mathrm{OH} \\
& \quad+\mathrm{H}_{2} \mathrm{~N}\left(\mathrm{CH}_{2}\right)_{3} \mathrm{NH}\left(\mathrm{CH}_{2}\right)_{2} \mathrm{NH}_{2}+4 \mathrm{HCHO} \rightarrow \mathbf{5} \\
& \\
& \quad \mathrm{Cu}^{2+}+2 \mathrm{H}_{2} \mathrm{~N}\left(\mathrm{CH}_{2}\right)_{3} \mathrm{NH}\left(\mathrm{CH}_{2}\right)_{2} \mathrm{OH} \\
& \quad+2 \mathrm{H}_{2} \mathrm{~N}\left(\mathrm{CH}_{2}\right)_{2} \mathrm{OH}+4 \mathrm{HCHO} \rightarrow \mathbf{1}
\end{aligned}
$$

A variety of copper(II) complexes have been prepared by metal-directed condensation involving amines and formaldehyde. For example, the mononuclear complex $\mathbf{5}$ has been prepared by the reaction of Eq. (1). ${ }^{10}$ In this work, we prepared new hydrogen-bonded dinuclear copper(II) complex $\left[\mathrm{Cu}\left(\mathrm{L}^{1}\right)\left(\mathrm{H}_{2} \mathrm{O}\right)\right]_{2}\left(\mathrm{ClO}_{4}\right)_{2} \cdot 2 \mathrm{H}_{2} \mathrm{O}$ (1) $\left(\mathrm{HL}^{1}=1\right.$-(2-hydroxyethylaminomethyl)-3-hydroxyethyl-1,3-diazacyclohexane) from the reaction of Eq. (2). In contrast to $\mathbf{2 - 4}, 1$ consists of two unsymmetrical mononuclear units; one 2-hydroxyethyl group of $\mathrm{HL}^{1}$ is attached to the secondary amino group, and the other to the tertiary amino group. Therefore, the present system offers a further opportunity to understand the deprotonation behaviors of the $N$-hydroxyethyl groups. Synthesis, crystal structure, and chemical properties of $\mathbf{1}$ are reported. The structural features and magnetic properties of $\mathbf{1}$ are compared with those of $\mathbf{2 - 4}$.

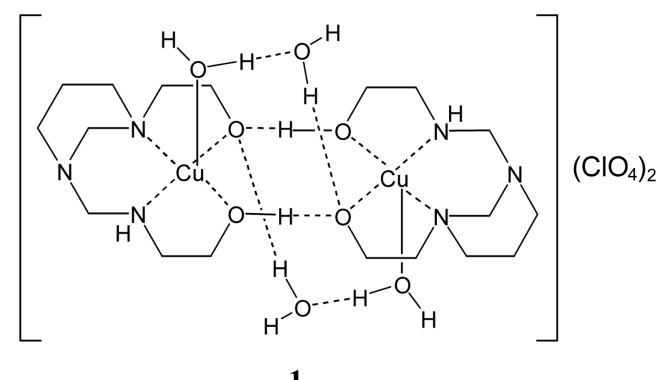

1

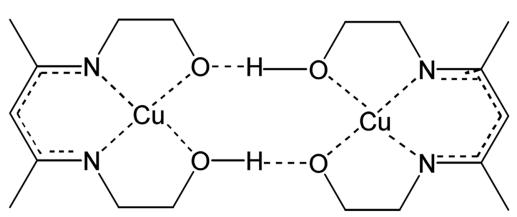<smiles>O=[N+]([O-])[C@H]1NCCO[C@@H]1O[C@@H]1NCCO1</smiles>

2

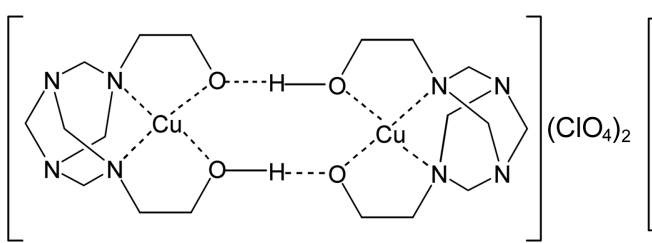




\section{Experimental}

Measurements. Infrared spectra were recorded with a Genesis II FT-IR spectrometer, electronic absorption spectra with an Analytik Jena Specord 200 UV/vis spectrophotometer, and conductance measurements with a Metrohm Herisau Conductometer E518. FAB-mass spectra were performed at the Korea Basic Science Institute, Daegu, Korea. Elemental analyses were performed at the Research Center for Instrumental Analysis, Daegu University, Gyeongsan, Korea. Magnetic susceptibility measurements were performed at the Korea Basic Science Institute, Seoul, Korea; the experiments were carried out in an applied field of $1000 \mathrm{Oe}$ between 2 and $300 \mathrm{~K}$ on a Quantum Design MPMS superconducting quantum interference device (SQUID) magnetometer. Diamagnetic corrections were made by using Pascal's constants.

Preparation of $\left[\mathrm{Cu}\left(\mathrm{L}^{1}\right)\left(\mathrm{H}_{2} \mathrm{O}\right)\right]_{2}\left(\mathrm{ClO}_{4}\right)_{2} \cdot 2 \mathrm{H}_{2} \mathrm{O}$ (1) $\left(\mathrm{HL}^{1}\right.$ $=1$-(2-hydroxyethylaminomethyl)-3-hydroxyethyl-1,3-diazacyclohexane). A methanol solution ( $c a .30 \mathrm{~mL})$ of $\mathrm{Cu}(\mathrm{OAc})_{2} \cdot \mathrm{H}_{2} \mathrm{O}$ (3.0 g, $\left.15 \mathrm{mmol}\right)$, 2-(3-aminopropylamino)ethanol (1.8 mL, $15 \mathrm{mmol}), 2$-aminoethanol (0.9 mL, 15 $\mathrm{mmol})$, and $35 \%$ formaldehyde $(5.2 \mathrm{~mL})$ was stirred for $>24 \mathrm{~h}$ at room temperature. After the addition of $\mathrm{NaClO}_{4}$ (ca. 2.0 $\mathrm{g})$, the mixture was stored in a refrigerator to precipitate a blue solid. The product was collected by filtration, washed with methanol, and dried in air. The pure product was obtained by fractional recrystallizations of the crude product from hot water-acetonitrile (1:1). Yield: $\sim 50 \%$. Anal. Found: C, 27.07; $\mathrm{H}, 6.17 ; \mathrm{N}, 10.70$. Calc. for $\mathrm{C}_{18} \mathrm{H}_{48} \mathrm{~N}_{6} \mathrm{CuCl}_{2} \mathrm{O}_{16}$ : C, 26.94; H, 6.03; N, 10.47\%. FAB mass $(\mathrm{m} / \mathrm{z}): 631.7$ $\left(\left[\mathrm{Cu}_{2}\left(\mathrm{~L}^{1}\right)_{2}+\mathrm{ClO}_{4}\right]^{+}\right), 530.6\left(\left[\mathrm{Cu}_{2}\left(\mathrm{~L}^{1}\right)_{2}-\mathrm{H}^{+}\right]^{+}\right)$. IR (Nujol mull, $\left.\mathrm{cm}^{-1}\right)$ : $3200(v \mathrm{~N}-\mathrm{H}), 3360(v \mathrm{O}-\mathrm{H}), 3520\left(v \mathrm{O}-\mathrm{H}, \mathrm{H}_{2} \mathrm{O}\right)$, $1100,\left(v \mathrm{Cl}-\mathrm{O}, \mathrm{ClO}_{4}\right)$.

Crystal Structure Determination. Single crystals of $\mathbf{1}$ suitable for X-ray diffraction analysis were obtained by slow evaporation of water-acetonitrile (1:1) solution of the complex. Structural measurement for the compound was performed on a STOE STADI4 four-circle diffractometer using graphite monochromatized Mo-K $\alpha$ radiation $(\lambda=$ $0.71069 \AA$ ) at $298(2) \mathrm{K}$. The unit cell parameters were calculated by least-squares fit of $2 \theta$ reflections in the ranges of $9.5<\theta<10.5^{\circ}$. Intensities of three reflections monitored periodically exhibited no significant variation. The structure was solved by direct method and refined on $F^{2}$ by fullmatrix least-squares procedures. ${ }^{11}$ All non-hydrogen atoms were refined using anisotropic thermal parameters. Hydrogen atoms were included in the structure factor calculation at idealized positions by using riding model, but not refined.

\section{Results and Discussion}

Crystal Structure. The dinuclear copper(II) complex 1 was prepared by the reaction (Eq. (2)) of formaldehyde with 2-(3-aminopropylamino)ethanol and 2-aminoethanol in the presence of $\mathrm{Cu}^{2+}$ ion. The ORTEP drawing of the mononuclear unit $\left[\mathrm{Cu}\left(\mathrm{L}^{1}\right)\left(\mathrm{H}_{2} \mathrm{O}\right)\right]\left(\mathrm{ClO}_{4}\right) \cdot \mathrm{H}_{2} \mathrm{O}$ in $\mathbf{1}$ with the atomic
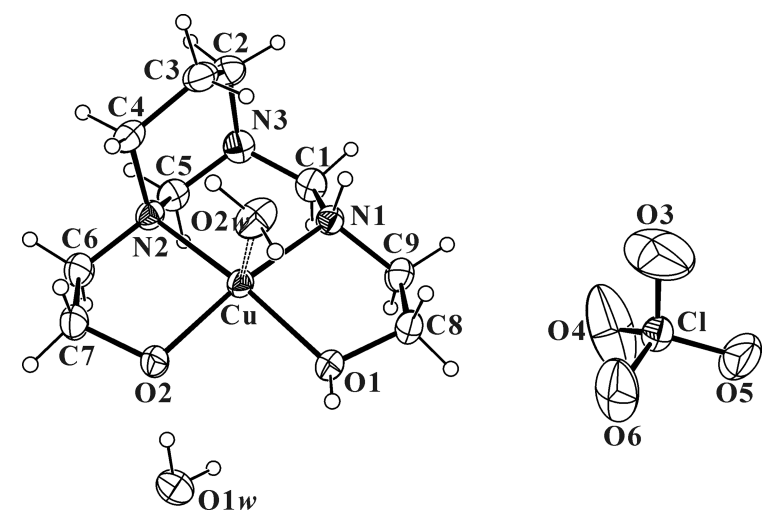

Figure 1. An ORTEP drawing of $\left[\mathrm{Cu}\left(\mathrm{L}^{1}\right)\left(\mathrm{H}_{2} \mathrm{O}\right)\right]\left(\mathrm{ClO}_{4}\right) \cdot \mathrm{H}_{2} \mathrm{O}$ in $\mathbf{1}$.

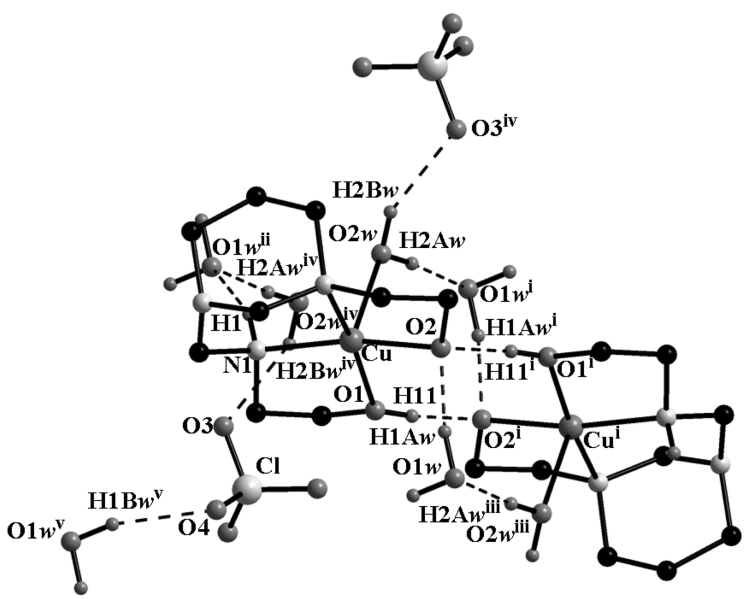

Figure 2. A view of the dimer 1 showing hydrogen bonds. The hydrogen bonds are shown as dotted lines. Symmetry code: (i) $1-x$, $1-\mathrm{y}, 1-\mathrm{z}$; (ii) $1+\mathrm{x}, \mathrm{y}, \mathrm{z}$; (iii) $1-\mathrm{x}, 1-\mathrm{y}, 1-\mathrm{z}$; (iv) $2-\mathrm{x}, 1-\mathrm{y}, 1-\mathrm{z}$; (v) $1-\mathrm{x}, 1-\mathrm{y},-\mathrm{z}$.

numbering scheme is shown in Figure 1. Figure 2 shows that 1 consists of two mononuclear units that are linked together by two hydrogen bonds and has an inversion center between the two metal ions. Two oxygen atoms $\{\mathrm{O}(1)$ and $\mathrm{O}(2)\}$ as well as the secondary and tertiary nitrogen atoms $\{\mathrm{N}(1)$ and $\mathrm{N}(2)\}$ are coordinated to the metal ion. The coordination geometry of each mononuclear unit is distorted squarepyramid with a water molecule at the apical position. The $\mathrm{O}(2)$ atom trans to the $\mathrm{N}(1)$ atom is involved in the $N$-ethoxo group, whereas the $\mathrm{O}(1)$ atom is involved in the $N$-hydroxyethyl group. This clearly shows that the coordinated $\mathrm{N}$ hydroxyethyl group trans to the secondary amino group is more readily deprotonated than that trans to the tertiary amino group. The six-membered chelate ring as well as the 1,3-diazacyclohexane ring has stable chair conformation. The apical water molecule $\{\mathrm{O}(2 w)\}$ and $\mathrm{N}-\mathrm{CH}_{2} \mathrm{CH}_{2} \mathrm{CH}_{2}-\mathrm{N}$ are $s y n$ with respect to the six-membered chelate ring.

The $\mathrm{Cu}$ atom is displaced by $c a$. $0.025 \AA$ from the mean $\mathrm{N}_{2} \mathrm{O}_{2}$ plane toward the apical water molecule. Table 2 shows that the $\mathrm{Cu}-\mathrm{N}(1)$ (secondary amine) distance $(2.015(3) \AA)$ is shorter than the $\mathrm{Cu}-\mathrm{N}(2)$ (tertiary amine) distance (2.042(3) $\AA$ ), as usual. The $\mathrm{Cu}-\mathrm{O}(2)$ distance $(1.926(2) \AA)$ involved in the $\mathrm{N}$-ethoxo group is distinctly shorter than the $\mathrm{Cu}-\mathrm{O}(1)$ 
Table 1. Crystal Data and Structure Refinement for $\mathbf{1}$

\begin{tabular}{ll}
\hline Empirical formula $(M)$ & $\mathrm{C}_{9} \mathrm{H}_{24} \mathrm{ClCuN}_{3} \mathrm{O}_{8}(401.30)$ \\
Crystal system (space group) & monoclinic $\left(P 2_{1} / n\right)$ \\
$a / b / c(\AA)$ & $7.8730(8) / 23.634(2) / 9.3619(9)$ \\
$\beta\left({ }^{\circ}\right)$ & $108.379(7)$ \\
$V\left(\AA^{3}\right)$ & $1653.1(3)$ \\
$Z$ & 4 \\
$D_{\text {calc }}\left(\mathrm{g} \mathrm{cm}^{-3}\right)$ & 1.612 \\
$\mu\left(\mathrm{cm}^{-1}\right)$ & 1.523 \\
$F(000)$ & 836 \\
$\theta$ range for data collection $\left({ }^{\circ}\right)$ & $1.72-27.45$ \\
Absorption correction & $\mathrm{T}_{\min }=0.6527, \mathrm{~T}_{\max }=0.9029$ \\
Index ranges & $-10 \leq h \leq 9,0 \leq k \leq 30,0 \leq l \leq 12$ \\
Reflections collected & 3777 \\
Independent reflections & 3777 \\
Reflections observed $(>2 \sigma)$ & 3273 \\
Data Completeness & 99.8 \\
Data / restraints / parameters & $3777 / 0 / 200$ \\
Goodness-of-fit on $F^{2}$ & 1.060 \\
Final R indices $[I>2 \sigma(I)]$ & $R_{1}=0.045, w R_{2}=0.121$ \\
$R$ indices (all data) & $R_{1}=0.054, w R_{2}=0.131$ \\
Largest diff. peak and hole $\left(\mathrm{e} \AA^{-3}\right)$ & 0.86 and -0.55 \\
\hline
\end{tabular}

Table 2. Bond Distances $(\AA)$ and Angles $\left(^{\circ}\right)$ of 1

\begin{tabular}{llll}
\hline $\mathrm{Cu}-\mathrm{O}(1)$ & $1.994(2)$ & $\mathrm{Cu}-\mathrm{O}(2)$ & $1.926(2)$ \\
$\mathrm{Cu}-\mathrm{N}(1)$ & $2.015(3)$ & $\mathrm{Cu}-\mathrm{N}(2)$ & $2.042(3)$ \\
$\mathrm{Cu}-\mathrm{O}(2 w)$ & $2.325(2)$ & $\mathrm{O}(1)-\mathrm{C}(8)$ & $1.434(4)$ \\
$\mathrm{N}(1)-\mathrm{C}(1)$ & $1.509(4)$ & $\mathrm{N}(1)-\mathrm{C}(9)$ & $1.494(4)$ \\
$\mathrm{N}(2)-\mathrm{C}(4)$ & $1.492(4)$ & $\mathrm{N}(2)-\mathrm{C}(5)$ & $1.505(4)$ \\
$\mathrm{N}(3)-\mathrm{C}(1)$ & $1.437(5)$ & $\mathrm{N}(3)-\mathrm{C}(2)$ & $1.470(5)$ \\
$\mathrm{N}(3)-\mathrm{C}(2)$ & $1.433(5)$ & $\mathrm{Cu} \cdots \mathrm{Cu}^{i}$ & $5.037(2)$ \\
$\mathrm{O}(1) \cdots \mathrm{O}(2)^{i}$ & $2.531(3)$ & $\mathrm{O}(1)-\mathrm{H}(11)$ & 0.820 \\
& & & \\
$\mathrm{O}(1)-\mathrm{Cu}-\mathrm{O}(2)$ & $91.2(2)$ & $\mathrm{O}(1)-\mathrm{Cu}-\mathrm{N}(2)$ & $168.6(2)$ \\
$\mathrm{O}(2)-\mathrm{Cu}-\mathrm{N}(1)$ & $169.6(2)$ & $\mathrm{O}(1)-\mathrm{Cu}-\mathrm{N}(1)$ & $84.2(2)$ \\
$\mathrm{O}(2)-\mathrm{Cu}-\mathrm{N}(2)$ & $86.9(2)$ & $\mathrm{N}(1)-\mathrm{Cu}-\mathrm{N}(2)$ & $95.7(2)$ \\
$\mathrm{O}(1)-\mathrm{Cu}-\mathrm{O}(2 w)$ & $90.7(2)$ & $\mathrm{O}(2)-\mathrm{Cu}-\mathrm{O}(2 w)$ & $95.2(2)$ \\
$\mathrm{N}(1)-\mathrm{Cu}-\mathrm{O}(2 w)$ & $94.2(2)$ & $\mathrm{N}(2)-\mathrm{Cu}-\mathrm{O}(2 w)$ & $100.7(2)$ \\
$\mathrm{C}(1)-\mathrm{N}(3)-\mathrm{C}(2)$ & $117.5(3)$ & $\mathrm{C}(1)-\mathrm{N}(3)-\mathrm{C}(5)$ & $114.7(3)$ \\
$\mathrm{C}(2)-\mathrm{N}(3)-\mathrm{C}(5)$ & $112.1(3)$ & & \\
\hline
\end{tabular}

Symmetry code: (i) $1-\mathrm{x}+1,-\mathrm{y},-\mathrm{z}+1$

distance (1.994(2) $\AA$ ). The in-plane $\mathrm{Cu}-\mathrm{O}(1)$ and $\mathrm{Cu}-\mathrm{O}(2)$ distances are shorter than the $\mathrm{Cu}-\mathrm{N}$ distances. The apical $\mathrm{Cu}-$ $\mathrm{O}(2 w)\left(\mathrm{H}_{2} \mathrm{O}\right)$ distance $(2.325(2) \AA)$ is considerably longer than the in-plane $\mathrm{Cu}-\mathrm{O}$ and $\mathrm{Cu}-\mathrm{N}$ distances. The $\mathrm{N}(1)-\mathrm{Cu}-$ $\mathrm{N}(2)$ angle $\left(95.7(2)^{\circ}\right)$ involved in the six-membered chelate ring is larger than the $\mathrm{O}(1)-\mathrm{Cu}-\mathrm{O}(2)$ angle $\left(91.2(2)^{\circ}\right)$. The $\mathrm{O}(1)-\mathrm{Cu}-\mathrm{N}(2)$ and $\mathrm{O}(2)-\mathrm{Cu}-\mathrm{N}(1)$ angles (168.6(2) and $169.6(2)^{\circ}$, respectively) are deviated from $180^{\circ}$. The O-Cu$\mathrm{O}(2 w)$ and $\mathrm{N}-\mathrm{Cu}-\mathrm{O}(2 w)$ angles are also deviated from $90^{\circ}$. The N(3)-C distances (1.433(5)-1.470(5) $\AA$ ) are distinctly shorter than other N-C bond distances. Furthermore, C$\mathrm{N}(3)$-C angles (112.1(3), 114.7(3), and 117.5(3) $)$ are larger than $109.4^{\circ}$. This indicates the $\mathrm{sp}^{3}$-hybridized N(3) atom is restrained because of the angle strain arising from the ring
Table 3. Specified Hydrogen Bond Geometry $\left(\AA,{ }^{\circ}\right)$ for $\mathbf{1}$

\begin{tabular}{lcccc}
\hline $\begin{array}{l}\text { Donor(D)-H } \cdots \\
\text { Acceptor(A) }\end{array}$ & $d(\mathrm{D}-\mathrm{H})$ & $d(\mathrm{H} \cdots \mathrm{A})$ & $d(\mathrm{D} \cdots \mathrm{A})$ & $\begin{array}{c}\text { Angle } \\
(\mathrm{D}-\mathrm{H} \cdots \mathrm{A})\end{array}$ \\
\hline $\mathrm{O}(1)-\mathrm{H} 11 \cdots \mathrm{O}(2)^{\mathrm{i}}$ & 0.82 & 1.72 & $2.531(3)$ & 168.8 \\
$\mathrm{O} 1 w-\mathrm{H} 1 \mathrm{~A} w \cdots \mathrm{O}(2)$ & 0.96 & 1.76 & $2.704(4)$ & 168.2 \\
$\mathrm{O} 2 w-\mathrm{H}(2 \mathrm{~A}) \cdots \mathrm{O} 1 w^{\mathrm{i}}$ & 0.87 & 1.92 & $2.786(4)$ & 171.4 \\
$\mathrm{O} 1 w-\mathrm{H} 1 \mathrm{~B} w^{\cdots}{ }^{\mathrm{iii}}$ & 0.90 & 2.08 & $2.952(6)$ & 164.7 \\
$\mathrm{O} 2 w-\mathrm{H} 2 \mathrm{~B} w^{\cdots}{ }^{\text {Oiv }}{ }^{\text {iv }}$ & 0.89 & 2.15 & $2.978(6)$ & 154.5 \\
$\mathrm{~N} 1-\mathrm{H} 1 \cdots \mathrm{O} 1 w^{\mathrm{ii}}$ & 0.91 & 2.16 & $3.006(4)$ & 153.7 \\
\hline
\end{tabular}

Symmetry codes: (i) $-\mathrm{X}+1,-\mathrm{Y}+1,-\mathrm{Z}+1$; (ii) $\mathrm{X}+1, \mathrm{Y}, \mathrm{Z}$; (iii) $-\mathrm{X}+1$, $-\mathrm{Y}+1,-\mathrm{Z}$; (iv) $-\mathrm{X}+2,-\mathrm{Y}+1,-\mathrm{Z}+1$.

Table 4. Structural Features $(\AA)$ and Magnetic Parameters of the Complexes

\begin{tabular}{clllccc}
\hline Complex & $\mathrm{Cu} \cdots \mathrm{Cu}$ & $\mathrm{O}^{\cdots} \mathrm{O}^{\prime}$ & $\mathrm{Cu}^{-N^{a}}$ & $\mathrm{Cu}-\mathrm{O}^{a}$ & $g$ & $2 J, \mathrm{~cm}^{-1}$ \\
\hline $\mathbf{1}$ & $5.038(2)$ & $2.527(4)$ & 2.032 & 1.962 & 2.07 & -18.8 \\
$\mathbf{2}^{b}$ & 4.941 & 2.452 & 1.990 & 1.958 & 2.11 & -56 \\
$\mathbf{3}^{c}$ & $4.979(6)$ & $2.29(1)$ & 1.90 & 1.947 & 2.04 & -94 \\
$\mathbf{4}^{d}$ & 4.555 & 2.459 & 2.003 & 1.947 & 2.11 & -4.1 \\
\hline
\end{tabular}

${ }^{a}$ Average value of $\mathrm{Cu}-\mathrm{N}$ or $\mathrm{Cu}-\mathrm{O}$ distances. ${ }^{b}$ Ref. $6 .{ }^{c}$ Ref. $7 .{ }^{d}$ Ref. 8.

rigidity of the ligand. The $\mathrm{O}(1) \cdots \mathrm{O}(2)^{\mathrm{i}}$ distance (2.531(3) $\AA$ ) shows that two mononuclear units of $\mathbf{1}$ are linked together by relatively strong hydrogen bonds. One of the most remarkable structural features of the complex is that each lattice water molecule acts as a bridge between the two mononuclear units through hydrogen bonds; the $\mathrm{O}(2)$ atom of one mononuclear unit and the $\mathrm{O}(2 w)^{\mathrm{iii}}$ atom of the coordinated water molecule are hydrogen bonded to the water molecule involving $\mathrm{O}(1 w)$ atom (Figure 2 and Table $3)$. This also contributes to the stability of $\mathbf{1}$ as the dimeric form.

Table 4 shows that the average $\mathrm{Cu}-\mathrm{N}$ and $\mathrm{Cu}-\mathrm{O}$ distances (2.032 and $1.962 \AA$, respectively) of $\mathbf{1}$ are longer than those of 2-4. ${ }^{6-8}$ The $\mathrm{O}(1) \cdots \mathrm{O}(2)^{\mathrm{i}}$ distance (2.531(3) $\AA$ ) of $\mathbf{1}$ is also longer than the distances (2.29-2.46 $\AA$ ) of 2-4. As a result, the $\mathrm{Cu} \cdots \mathrm{Cu}$ distance $(5.037(2) \AA)$ is longer than those (4.555-4.979 $\AA$ ) of 2-4.

Spectra and Properties. The dinuclear complex 1 is quite stable in the solid state and in various solvents, such as nitromethane, acetonitrile and water. The molar conductance values of 1 measured in nitromethane $\left(162 \Omega^{-1} \mathrm{~mol}^{-1} \mathrm{~cm}^{2}\right)$, acetonitrile $\left(270 \Omega^{-1} \mathrm{~mol}^{-1} \mathrm{~cm}^{2}\right)$, and water-acetonitrile (3:1) $\left(198 \Omega^{-1} \mathrm{~mol}^{-1} \mathrm{~cm}^{2}\right)$ indicate that the complex is a $1: 2$ electrolyte. FAB mass spectrum of $\mathbf{1}$ measured in acetonitrile shows two groups of peaks corresponding to $\left[\mathrm{Cu}_{2}\left(\mathrm{~L}^{1}\right)_{2}+\right.$ $\left.\mathrm{ClO}_{4}\right]^{+}$and $\left(\left[\mathrm{Cu}_{2}\left(\mathrm{~L}^{1}\right)_{2}-\mathrm{H}^{+}\right]^{+}\right.$fragments at $\mathrm{m} / \mathrm{z} 631.7$ and 530.6 , respectively. The electronic absorption spectrum of 1 measured in Nujol mull shows a d-d band at $590 \mathrm{~nm}$, which is comparable with those of other square-pyramidal copper(II) complexes with $\mathrm{N}_{2} \mathrm{O}_{3}$-donor sets. ${ }^{5,9,12}$ The spectra measured in nitromethane, acetonitrile, and acetonitrilewater (1:3) also show the band at $594\left(\varepsilon=103 \mathrm{M}^{-1} \mathrm{~cm}^{-1}\right)$, $588 \mathrm{~nm}\left(\varepsilon=110 \mathrm{M}^{-1} \mathrm{~cm}^{-1}\right)$, and $600 \mathrm{~nm}\left(\varepsilon=115 \mathrm{M}^{-1} \mathrm{~cm}^{-1}\right)$, respectively. Electronic and FAB mass spectra of $\mathbf{1}$ as well as the molar conductance values strongly indicate that the 


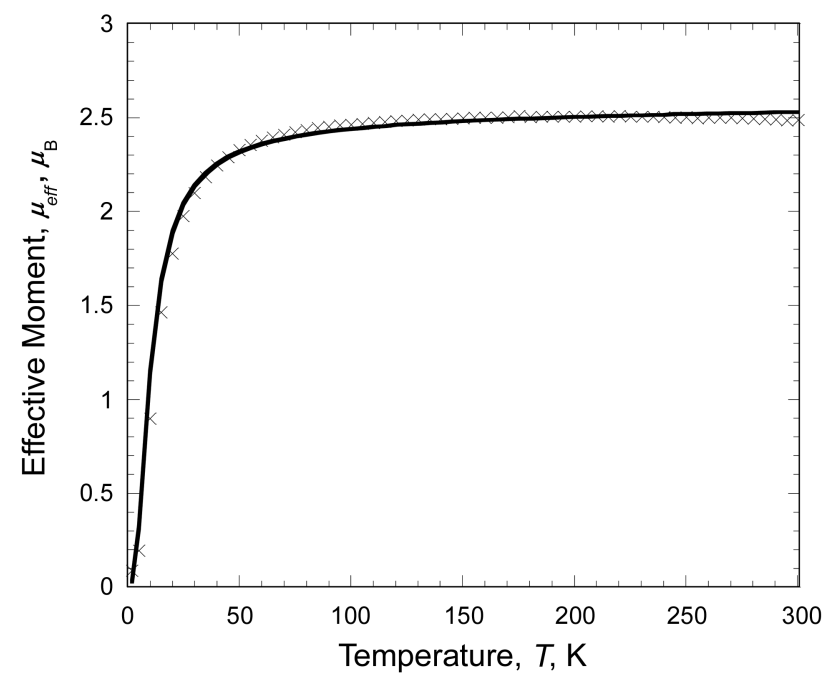

Figure 3. Fitting of effective magnetic moment versus temperature (K) data of 1 using dimer model of $S=1 / 2$ local spin. Solid line shows the best fit obtained.

hydrogen bonds between the two mononuclear units are so strong that the complex is quite stable as the dinuclear form even in the polar solvents. Although $\mathbf{1}$ is quite stable in the solvents, it is rapidly decomposed in acidic aqueous solutions; the decomposition reaction rate in $0.1 \mathrm{M} \mathrm{HClO}_{4}$ aqueous solution was found to be too fast to be measured by the ordinary method.

Magnetic susceptibilities $(\chi)$ of 1 were measured from 2 to $300 \mathrm{~K}$ to see the effects of the structural parameters on the magnetic properties. The effective magnetic moment, $\left(\mu_{\text {eff }}\right.$ $\left[=\left(8 \chi_{M} T\right)^{1 / 2}\right]$, is $2.49 \mu_{\mathrm{B}} / \mathrm{Cu}_{2}$ at room temperature. The value is slightly larger than $2.45 \mu_{\mathrm{B}}$ expected for independent two copper(II) ions $(\mathrm{S}=1 / 2, \mathrm{Cu}(\mathrm{II}), \mathrm{g}=2)$. Figure 3 shows that $\mu_{\text {eff }}(T)$ decreases monotonically as the temperature is lowed, indicating a weak antiferromagnetic interaction between the $\mathrm{Cu}$ (II) ions. The $\mu_{\text {eff }}(T)$ data was fit to an analytical expression for $c(T)$ for a coupled $S=1 / 2$ dinuclear spin model (Eq. (3)) based on the Hamiltonian $H=-2 J S_{1} \cdot S_{2}\left(S_{1}=\right.$ $\left.S_{2}=1 / 2\right){ }^{13}$ The fitting leads to a value of $2 J=-18.8 \mathrm{~cm}^{-1}$ with $g=2.07$ and a value of temperature independent paramagnetism (TIP) $=60 \times 10^{-6} \mathrm{emu} / \mathrm{mol}$. The relatively long $\mathrm{Cu} \cdots \mathrm{Cu}$ distance $(5.038(2) \AA)$ within the hydrogen-bonded dimer rules out direct interaction between the metal ions. Therefore, the antiferromagnetic coupling between two copper(II) ions of $\mathbf{1}$ may be attributed to a superexchange through the cooperative hydrogen bonds.

$$
\chi_{\mathrm{M}}=\frac{2 N \beta^{2} g^{2}}{3 k T}\left[1+\frac{1}{3} \exp (-2 J / k T)\right]^{-1}+\mathrm{TIP}
$$

The structural features of 1-4 and their magnetic parameters are listed in Table 4 for comparison. It is seen that the antiferromagnetic coupling for $\mathbf{1}$ is stronger than that for $\mathbf{4}$, in spite of its relatively long $\mathrm{Cu} \cdots \mathrm{Cu}$ and $\mathrm{O} \cdots \mathrm{O}$ distances. Unfortunately, we could not find any direct correlation between the coupling constants and the structural features of the complexes.

\section{Summary}

The dinuclear complex 1 with cooperative hydrogen bonds can be prepared by the metal-directed reaction of Eq. (2). This work shows that the coordinated hydroxyl group trans to the secondary amino group is deprotonated more readily than that trans to the tertiary amino group and acts as the hydrogen-bond accepter. The lattice water molecules in $\mathbf{1}$ act as bridges between the two mononuclear units through hydrogen bonds. The complex is quite stable as the dimeric form even in various polar solvents. The complex exhibits a weak antiferromagnetic interaction between the metal ions in spite of relatively long $\mathrm{Cu}{ }^{\cdots} \mathrm{Cu}$ distance. This strongly supports the suggestion that the antiferromagnetic behavior is closely related to the cooperative hydrogen bonds.

Supplementary Material. Crystallographic data for 1 have been deposited with the Cambridge Crystallographic Data Center (CCDC number 800643). Copies of the data may be obtained free of charge, on application to the director, CCDC, 12 Union Road, Cambridge CB2 IEZ, UK (http://www.ccdc.cam.ac.uk, fax: +44-1233-336-033, or email: deposit@ccdc.cam.ac.uk).

Acknowledgments. This research was supported in part by Basic Science Research Program through the National Research Foundation of Korea (NRF) funded by the Ministry of Education, Science and Technology (No. 2010-0007251).

\section{References}

1. Selmeczi, K.; Reglier, M.; Giorgi, M.; Speier, G. Coord. Chem. Rev. 2003, 245, 191.

2. (a) Mukherjee, P.; Drew, M. G. B.; Estrader, M.; Diaz, C.; Ghosh, A. Inorg. Chim. Acta 2008, 361, 161. (b) Chaudhuri, P.; Wagner, R.; Weyhermuller, T. Inorg. Chem. 2007, 46, 5134.

3. (a) Ambrosi, G.; Formica, M.; Fusi, V.; Giorgi, L.; Macedi, E.; Micheloni, M.; Paoli, P.; Rossi, P. Inorg. Chem. 2009, 48, 10424. (b) Ferrando-Soria, J.; Castellano, M.; Yuste, C.; Llort, F.; Julve, M.; Fabelo, O.; Ruiz-Perez, C.; Ruiz-Perez, C.; Stiriba, S.-P.; Ruiz-Garcia, R.; Cano, J. Inorg. Chim. Acta 2010, 363, 1666.

4. (a) Das, O.; Adarsh, N. N.; Paul, A.; Paine, T. K. Inorg. Chem. 2010, 49, 541. (b) Das, S.; Banerjee, P.; Peng, S.-M.; Lee, G.-S.; Kim, J.; Goswami, S. Inorg. Chem. 2006, 45, 562.

5. Kang, S.-G.; Lee, Y. H.; Jeong, J. H. Inorg. Chem. Commun. 2007, $10,1429$.

6. Bertrand, J. A.; Fuita, E.; VanDerveer, D. G. Inorg. Chem. 1980, 19, 2022.

7. Bertrand, J. A.; Black, T. D.; Eller, P. G.; Helm, F. G.; Mahmood, R. Inorg. Chem. 1976, 15, 2965.

8. Arulsamy, N.; Glerup, J.; Hodgson, D. J. Inorg. Chem. 1994, 33, 2066.

9. Shevchenko, D. V.; Petrusenko, S. R.; Kokozay, V. N.; Zhigalko, M. V.; Zubatyuk, R. I.; Shishkin, O. V.; Skelton B. W.; Raithby, P. T. Inorg. Chim. Acta 2005, 358, 3889.

10. Kang, S.-G.; Nam, K.; Kim, S.-D. Bull. Korean Chem. Soc. 2004, 25, 1973.

11. (a) STOE STADI4, X-RED \& X-SHAPE, X-ray Structure Evaluation Package; STOE-Cie Gmbh: Hilpertstrase 10, D64295, Darmstadt, Germany, 1996. (b) Sheldrick, G. M. Acta Cryst. 1990, A46, 467. (c) Sheldrick, G. M. Acta Cryst. 2008, A64, 112-122.

12. Lever, A. B. P. Inorganic Electronic Spectroscopy, 2nd ed.; Elsevier Science Publisher B. V: New York, 1984; pp 554-572.

13. Kahn, O. Molecular Magnetism; VCH: New York, 1993. 